\title{
Distribution and intensity of glaciotectonic deformation in Denmark
}

\author{
PETER ROLL JAKOBSEN
}

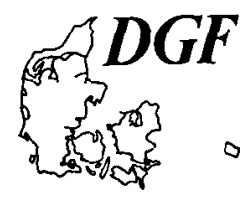

\author{
Jakobsen, P. R.: Distribution and intensity of glaciotectonic deformation \\ in Denmark. Bulletin of the Geological Society of Denmark. Vol. 42, pp. \\ 175- 185. Copenhagen 1996-02-01. \\ https://doi.org/10.37570/bgsd-1995-42-14
}

Glaciotectonic deformation has a large impact on the stratigraphical and lithological variability of Quaternary deposits and the shallow subsurface pre-Quaternary sediments. Mapping of the distribution of glaciotectonic deformation involving pre-Quaternary and interglacial deposits has been carried out, and the density of glaciotectonic deformation analysed, on the basis of data from the well database ZEUS, at the Geological Survey of Denmark.

Glaciotectonic deformation is widespread in Denmark. It is recognised in glacial terrains within morphological well-defined glaciotectonic complexes, and in areas with no obvious glaciotectonic related morphology as well as in areas covered with postglacial deposits. The dislocated bedrock is usually not transported for long distances, although rafts of pre-Quaternary bedrock may be transported up to $50 \mathrm{~km}$ or more.

On a large scale, regions have been located showing high intensity of glaciotectonic deformation. Some of these regions are in good agreement with records from exposures and the geomorphology, others cannot be recognised without well log information.

Peter Roll Jakobsen, Geological Survey of Denmark, Thoravej 8, DK 2400 Kobenhavn NV, Denmark. October 27th 1995.

\section{Introduction}

Glaciotectonic deformation has had a significant impact on the glacial landscape with respect to morphogenesis and the distortion of sediments. The structures produced by the advancing glacier form an integrated part of the kinetostratigraphic concept, which is used for the description of the glaciogeological development (Berthelsen 1978, Houmark-Nielsen 1987, Pedersen 1993). The structural relationships within and between glaciotectonic complexes form the foundation for the reconstruction of the regional glacier advance.

In addition glaciotectonic deformation is an essential feature in the study of variability of near surface deposits. Within the glaciotectonic deformation complex there is a disruption of the strata due to thrusting, and the lateral and vertical variability of sediment type is very high. Knowledge of the existence of glacio-tectonics and the degree of the glaciotectonic variability is crucial in many aspects, as it has serious implications in the fields of raw materials, hydrogeology and soil mechanics.
Gry (1940) demonstrated the relationship between the structural trend and the morphology of the ice push ridges in the Limfjord area, and explained the genesis of the structures as well as the morphology as a result of active glacier push. Mapping of glaciotectonic features in Denmark has primarily been conducted by means of glaciotectonic landforms based on morphological studies. A genetic classification and description of the morphology of the glacial landscape in Denmark was first undertaken by Milthers (1948). Later Smed $(1962,1982)$ presented a regional morphogenetic map of Denmark. He introduced and defined glaciotectonic landforms in his classification, such as pushmoraines and cupola hills. An expanded classification of glaciotectonic landforms was given by Aber (1988) and Aber, Croot \& Fenton (1989). They proposed five types of glaciotectonic landforms. These five types are listed below and locations with examples of the five glaciotectonic landforms within Denmark are shown in Figure 1. 


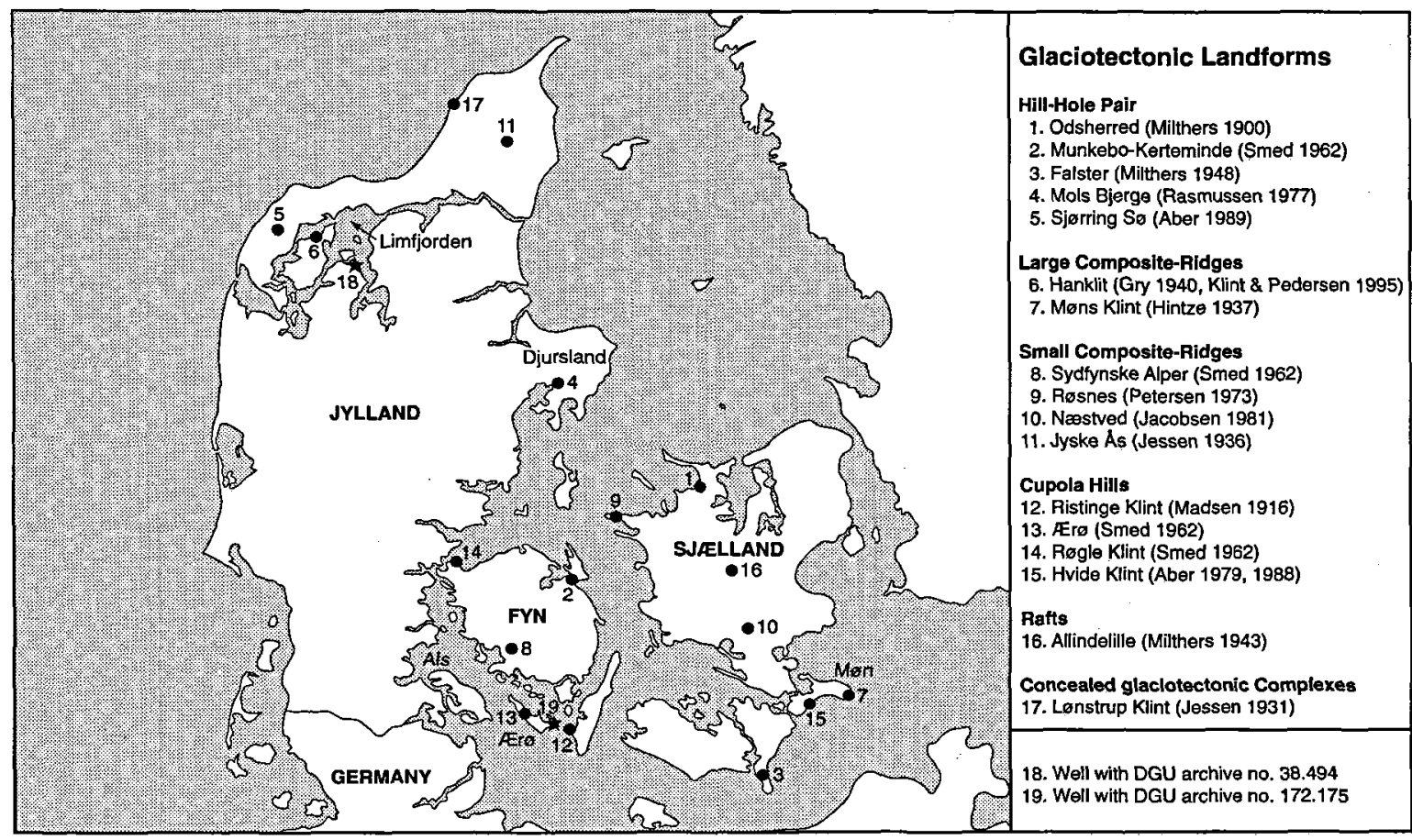

Fig. 1. Sites displaying glaciotectonic landforms in Denmark according to Aber (1988) and Aber, Croot \& Fenton (1989).

1) The Hill-Hole Pair is a combination of an ice-pushed ridge and a discrete ice-scooped basin. The ridge is situated downglacier of the associated hole, which is the source depression of the ice-shoved hill.

2) The Large Composite-Ridges (up to $100-200 \mathrm{~m}$ in height) are a system of subparallel ridges, often arcuate in plan; they often include a substantial volume of contorted pre-Quaternary bedrock.

3) The Small Composite-Ridges are also a system of subparallel ridges, arcuate in plan, but they are smaller ( $<100 \mathrm{~m}$ in height) than the large composite-ridges; they are usually composed largely of unconsolidated Quaternary strata.

4) The Cupola-Hill morphology is formed by a number of conspicuous hills that lack the transverse ridge morphology of ice-shoved hills. They generally have a smoothed dome to elongated drumlin shape, with a till cover. The glaciotectonic origin of such hills can only be recognised with subsurface evidence from exposures or drilling logs.

5) The Megablocks (also called raft, floe or scale) are large allochthonous masses of dislocated bedrock. The megablocks are more or less horizontal, slightly deformed, and often buried under or within thick masses of drift. There is usually no or only little morphological evidence of their presence. Hence they are very difficult to distinguish without drilling logs or exposures.
In addition to these five types of glaciotectonic landforms, the concealed glaciotectonic complex is an important glaciotectonic feature. A glaciotectonic complex covered by younger sediments does not express any glacial morphology. However the structures may be very spectacular and result in highly deformed bedding and disturbed stratigraphy. Concealed glacio-tectonic complexes may be investigated in cliff exposures, and can be recognised in wells.

Recently, mapping of glaciotectonics in North America has been carried out (Aber et al. 1993). The mapping included morphological elements (ice-shoved hills and source basins), as well as concealed structures and basement faults related to loading/unloading of ice. It is planned to conduct a similar mapping of glaciotectonics in Europe (Croot \& Michalak 1993).

In many situations, glaciotectonic landforms are significantly altered by subsequent subglacial processes, or later ice advances, e.g. Ærø (Smed 1962). In other situations such landforms might be buried under late glacial or postglacial deposits, e.g. Lønstrup Klint (Jessen 1931). In cases where information from morphology and exposures are not available, information from wells constitutes an important supplement.

Preliminary mapping of glaciotectonic structures and features in southeast Jylland has been conducted based on surface morphology, records of glaciotectonics from exposures and information from well logs (Houmark- 
Nielsen 1986); the use of well data facilitates more widespread correlation and reveals information on concealed glaciotectonics.

The aim of this work is to map the distribution of concealed glaciotectonic deformation in Denmark, based on records from well logs stored in the well database at the Geological Survey of Denmark, and to analyse the intensity of the glaciotectonic deformation.

\section{Methods}

\section{Data source}

The data source used in this mapping is the ZEUS well database (Gravesen \& Fredericia 1984) at the Geological Survey of Denmark. The ZEUS database contains information from about 140,000 well logs. The distribution of the wells is shown in Figure 2. The information from the well logs are mainly from water supply wells but also from raw material, geotechnical and scientific borings. The database contains details of geology, hydrogeology and well technical properties. The geological data are registered in a mnemo-technical code, with a two letter symbol, indicating the lithology as well as the stratigraphy, which is used in the computerised search for concealed glacio-tectonic deformation.

\section{Recognising deformation in wells}

Glaciotectonic thrusting of sedimentary rocks causes stratigraphic disruption and in some cases repetition of the strata. Repeated drift deposits are usually difficult or impossible to recognise in wells. However, if preQuaternary bedrock is involved in the thrusting, it will often be thrusted on top of Quaternary drift, and thereby

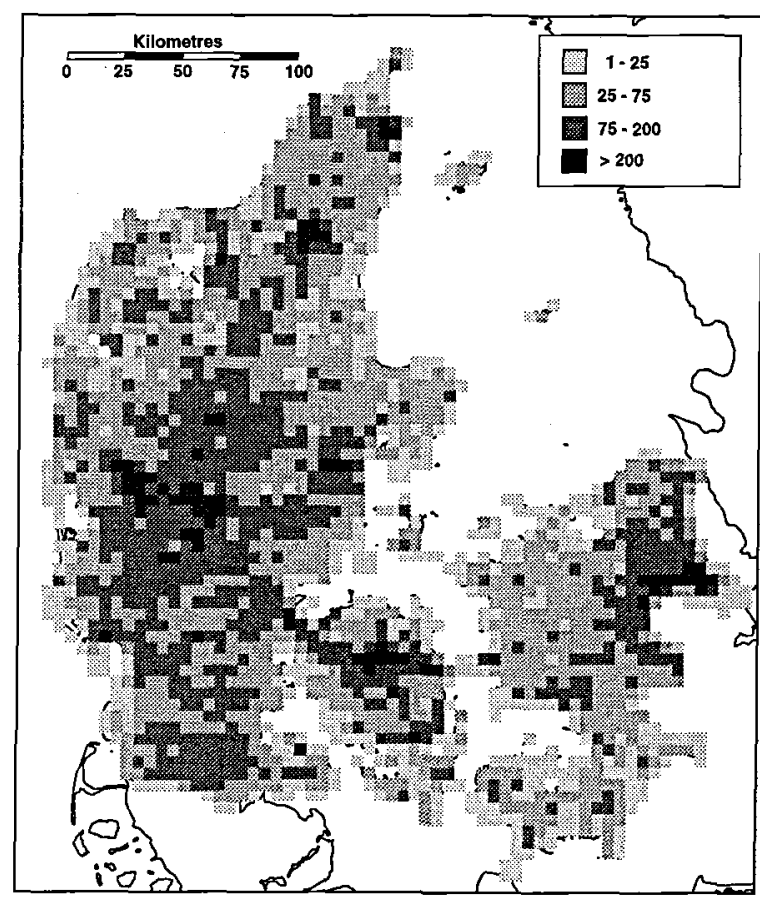

Fig. 2. Grid map showing the distribution of wells stored in the ZEUS database. The size of a grid cell is $5 \times 5 \mathrm{~km}$.

act as a stratigraphic marker in the deformation complex. This situation is exemplified by the large composite-ridges at Hanklit on the island of Mors (Fig. 3, for location see Fig. 1). In the Hanklit cliff, a thinskinned thrust complex is exposed, forming a composite ridge system (Klint \& Pedersen 1995). Within this deformation complex, Palaeocene-Eocene diatomite is thrusted on top of Weichselian drift. A similar sequence is recorded by logs in the well shown in Figure 5 (DGU

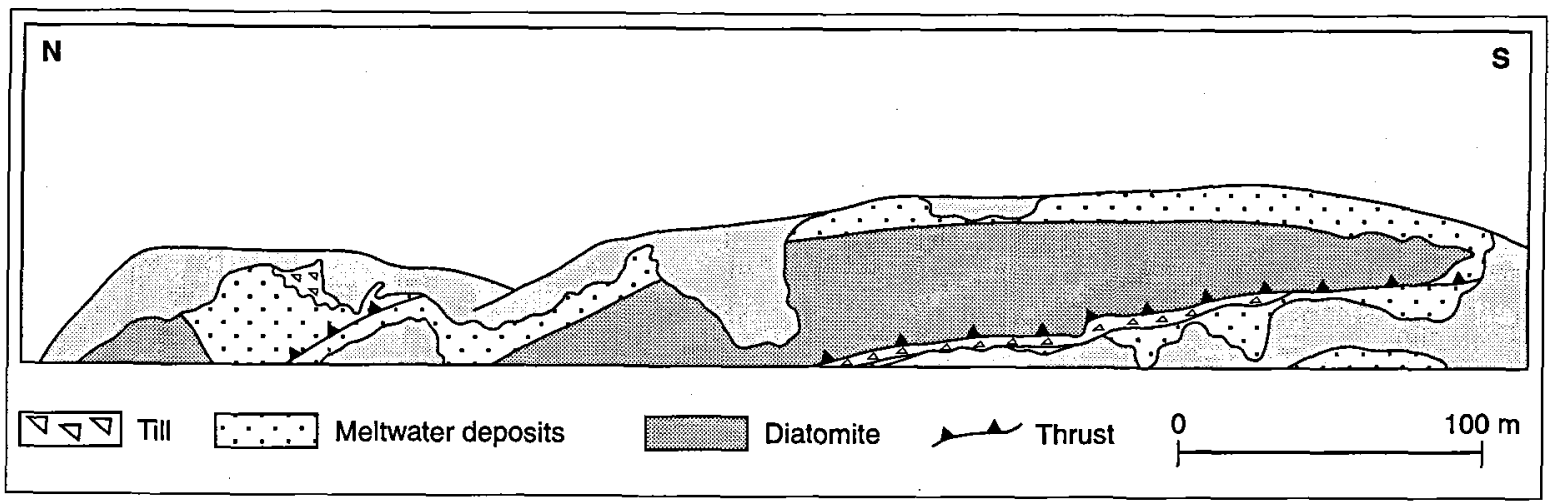

Fig. 3. A section through the thin-skinned thrust complex forming a Large Composite Ridge system at Hanklit on the island of Mors (re-drawn after Jensen 1992). In the section, Palaeocene-Eocene diatomite is thrusted onto Quaternary drift. 


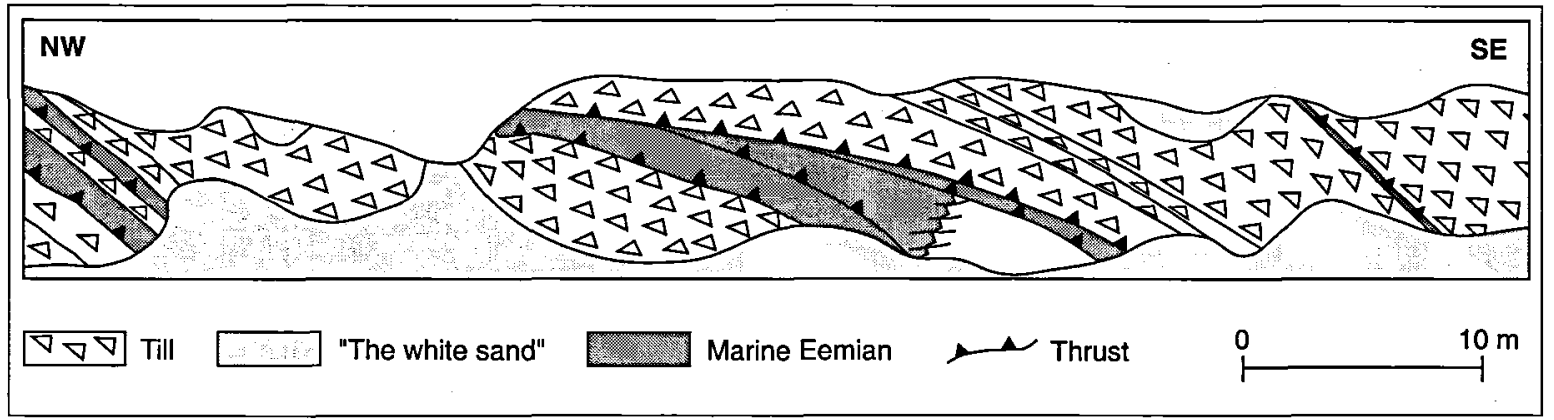

Fig. 4. Coastal cliff profile (Hansen 1994) exposing the interior of the Cupola Hill landscape at Bregninge Mark, $Æ$ Erø. Dislocated Eemian marine deposits are repeated with intervening drift deposits

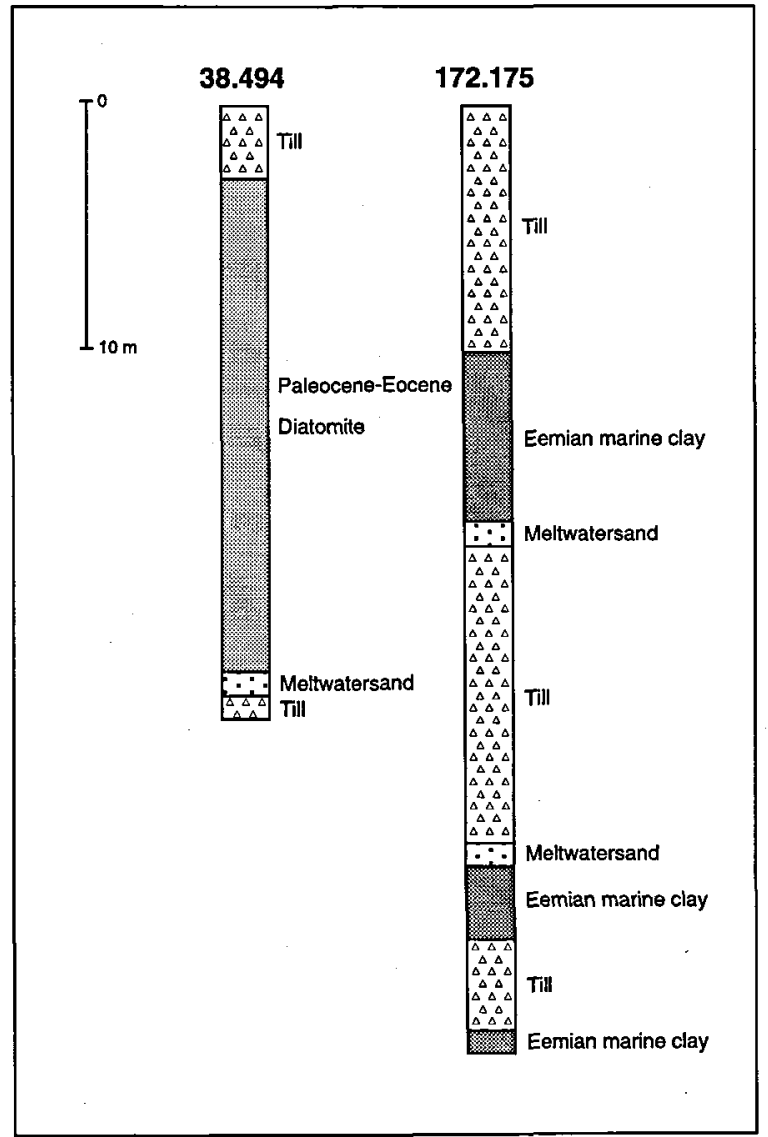

Fig. 5. Well log profiles indicating glaciotectonic dislocation. In well $\log$ no. 38.494, Palaeocene-Eocene diatomite overlies Quaternary drift displaying a similar succession as seen in the dislocation complex at Hanklit (Fig. 3). In well $\log$ no. 172.175, Eemian marine deposits are recorded three times with intervening drift, displaying a similar succession as seen in the cliff sections on \#rø (Fig. 4). archive No. 38.494, for location see Fig. 1). In this well Eocene-Palaeocene diatomite rests on Quaternary drift, indicating that the well penetrated glaciotectonic dislocated Tertiary bedrock (Jakobsen \& Pedersen 1993).

If the bedrock is dislocated as rafts or megablocks, it will have the same implications for stratigraphic variability in a well log as thrusting in thin-skinned thrust complexes i.e. the pre-Quaternary bedrock overlies Quaternary drift. In order to differentiate between the two processes, it is necessary to make an interpretation of the local geology. In any case, the presence of preQuaternary bedrock overlying Quaternary drift is indicative of glaciotectonic deformation. A search was made in the database for wells in which bedrock was found above drift and 1210 were detected.

Repetition of a well-defined unit such as interglacial Eemian marine clay can also be used to recognize glaciotectonic deformation. On the island of Ærø dislocations of interglacial marine clay have been described (Berthelsen 1979, Hansen 1987, 1994). The Interglacial marine clay has been thrusted and folded during several Weichselian ice advances. In a coastal cliff section near Bregninge Mark on Ærø, slices of marine Eemian deposits are thrusted on top of each other, with intervening Weichselian till (Hansen 1994) (Fig. 4). In a well situated on the island of Ærø (DGU archive no. 172.175 in Fig. 5, for location see Fig. 1), interglacial marine clay of Eemian age is repeated three times with intervening till and meltwater sand. This indicates Weichselian glaciotectonic deformation, causing a repetition of the interglacial strata. On the assumption that repetition of the same interglacial unit in a well is indicative of glaciotectonic dislocation, a search was made in the database for wells with two interglacial marine clays with intervening drift and 49 were detected. The description and interpretation was subsequently checked for each well, to ensure that it represented a repetition of the same interglacial sequence.

Information of glaciotectonic deformation derived from well logs can also be extracted from geological basisdata maps. Not all wells kept in the ZEUS database are represented on the geological basisdata maps, 
Fig. 6. Distribution of wells with well logs in which dislocated pre-Quaternary bedrock is recorded above Quaternary drift.

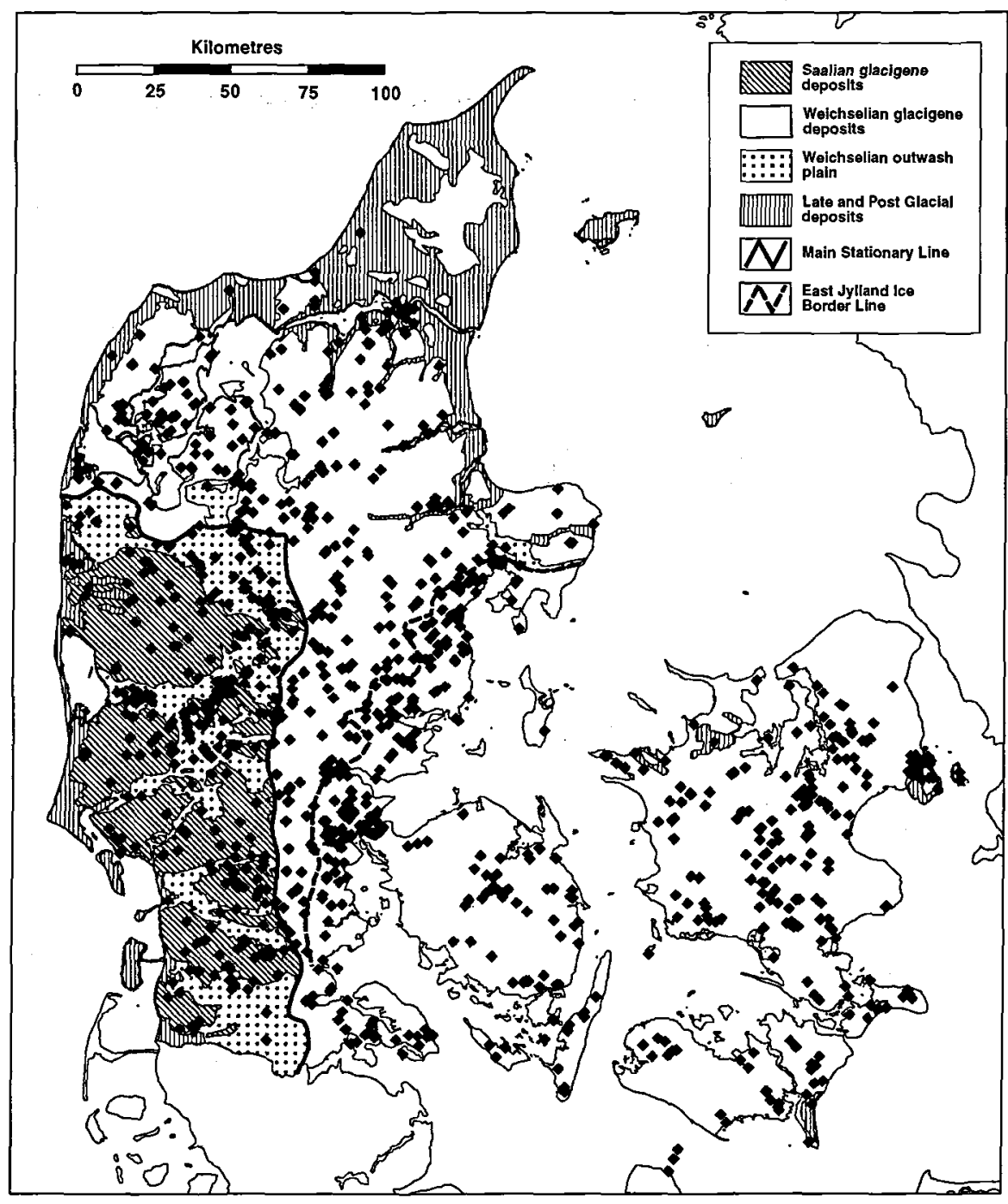

however, as it is not possible, for practical reasons, to display all wells on the maps.

\section{Mapping with GIS}

The wells in which glaciotectonic dislocations have been recognized, were located in a computer search, and subsequently plotted by means of ZETA. ZETA is a computer based Geographical Information System (GIS) developed at the Geological Survey of Denmark for capture, management and plotting of georeferenced data (Jørgensen et al. 1993). The wells showing a record of concealed glaciotectonic deformation are plotted along with the main geological features in the Quaternary landscape, which have been digitalised from Hansen \& Milthers (1954). The grid maps used to show the distribution of wells stored in the ZEUS database
(Fig. 2) and the density of concealed glaciotectonic deformation (Fig. 8) are computed in the statistical program SAS, and subsequently plotted using the ZETA program.

\section{Distribution of concealed glaciotectonic deformation}

Wells showing evidence of dislocated pre-Quaternary bedrock are widespread throughout Denmark (Fig. 6). They are found inside the Weichselian Main Stationary Line, as well as outside. The lithostratigraphical units found as dislocated pre-Quaternary bedrock are the same as those observed at the pre-Quaternary surface and the distribution corresponds fairly well with the distribution pattern of the pre-Quaternary units (Hå- 


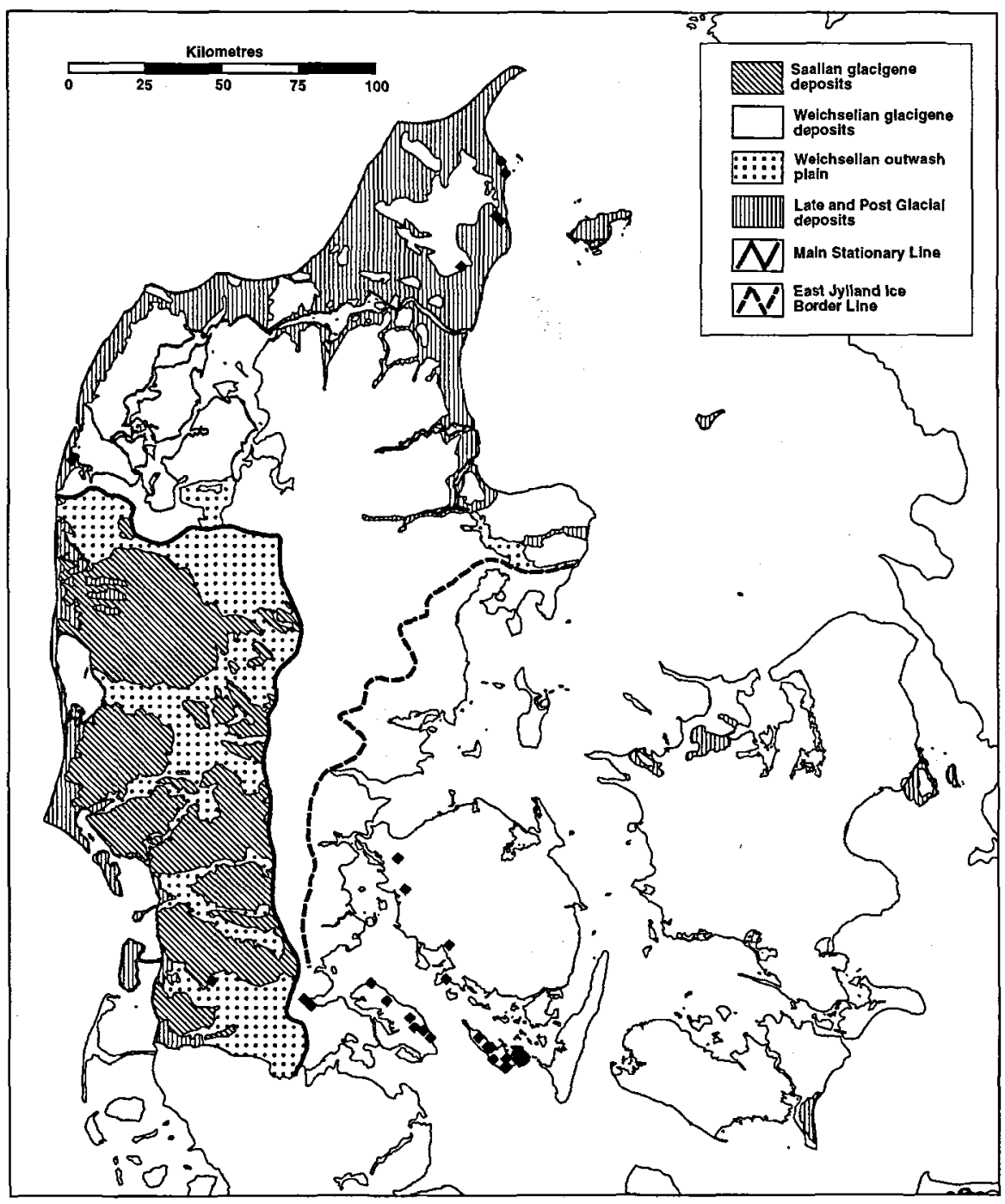

Fig. 7. Distribution of wells with well logs in which dislocated interglacial marine deposits are repeated with intervening drift.

kansson \& Pedersen 1992). An exception, however, is the presence of dislocated Cretaceous limestone rafts in the central part of Sjælland. They are also reported near Allindelille (Fig. 1) by Milthers (1943) who suggested that the most likely provenance of the rafts was southeast Sjælland, with a transport distance of at least $50 \mathrm{~km}$. Similar far-travelled limestone rafts have also been reported from Skåne, south Sweden (Ringberg et al. 1984).

Most of the recognised dislocated marine interglacial deposits in wells are found inside the Main Stationary Line (Fig. 7). It is mainly Eemian marine deposits, and they are restricted to areas of Eemian marine deposition (Konradi 1976, Knudsen 1994). In southwest Jylland, outside the Main Stationary Line, a dislocated sequence of marine Holsteinian deposits is recognised (Andersen 1963, Knudsen \& Penny 1987).
Outside the Main Stationary Line, the concealed deformation is observed both in the 'hilly islands', where Saalian drift primarily constitutes the surface geology, and they are found below the surrounding late Weichselian outwash plain deposits which covers the Saalian drift. The landscape within the 'hilly islands' does not display distinct morphological evidence of glaciotectonic deformation. The morphological features seen are related to 120,000 years of subaerial erosion of soft sediment, and deposition of eolian sand.

In the Nederlands and Germany, the Saalian ice-push ridges form distinct morphological features (Meyer 1983, van der Wateren 1985, Kluiving 1994). The lack of glaciotectonic landforms in the Saalian 'hilly-islands' thus cannot be explained solely by post-Saalian subaerial erosional processes. The landscape in the "hillyislands' was probably initially formed or modified by 
Fig. 8. Grid map displaying the intensity of glaciotectonic deformation recorded in wells. Each grid cell is $5 \times 5 \mathrm{~km}$.

The density in each grid cell is shown as the number of wells with recorded deformation in per mille of the total number of wells.

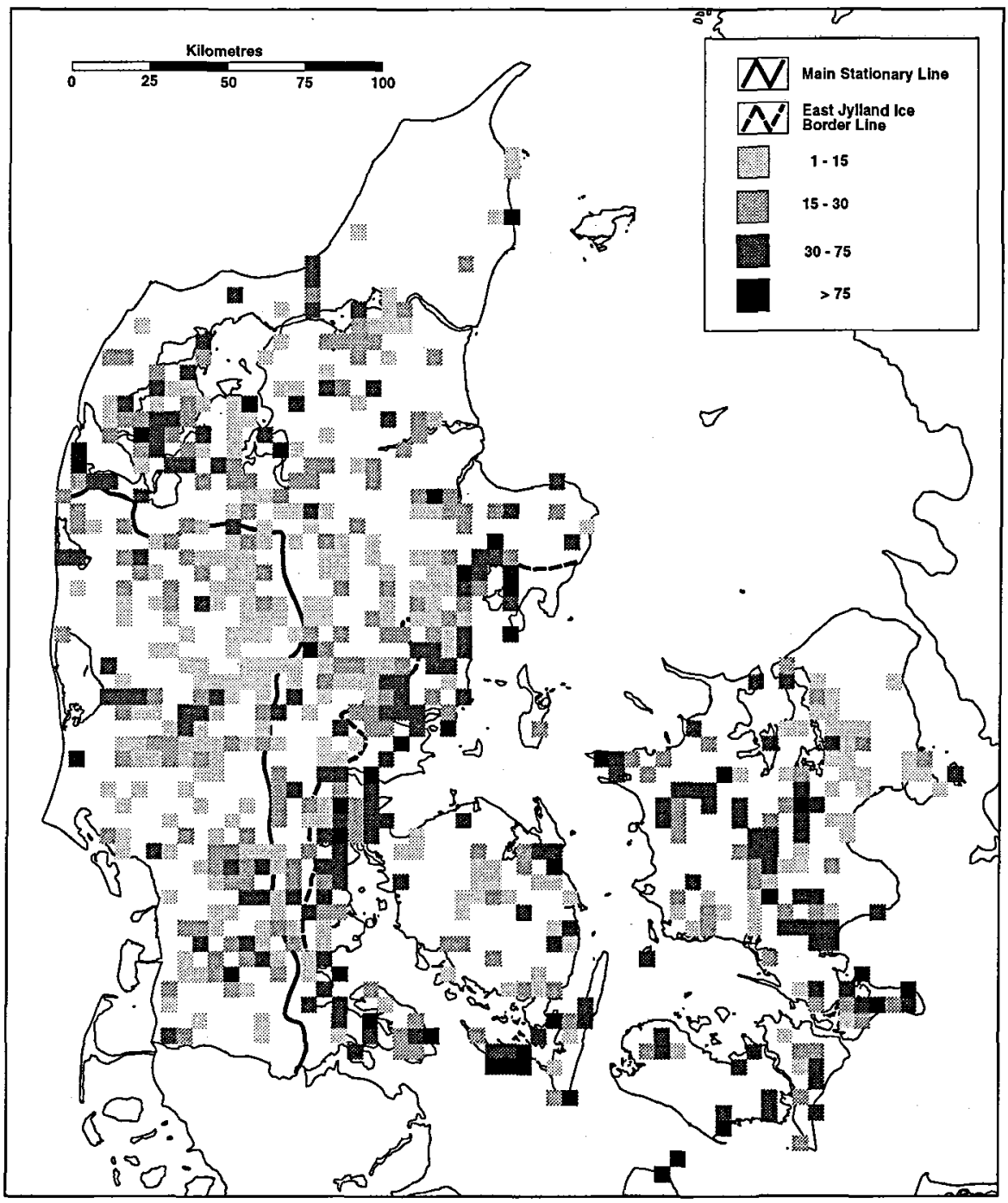

subglacial erosional and/or depositional processes. As the 'hilly islands' display significant concealed glaciotectonic deformation, they could be classified as modified cupola-hill landscape.

Within the Main Stationary Line, the wells showing evidence of dislocated pre-Quaternary bedrock are found associated with glaciotectonic landforms, as well as in areas with no particular glaciotectonic morphology, and in areas covered with post glacial deposits. They are found throughout the Danish area except in the northern part of Jylland. This is most likely because the pre-Quaternary surface is situated more than $100 \mathrm{~m}$ below surface in this area, and most of the wells are not drilled to a depth where dislocated pre-Quaternary bedrock could be expected. Glaciotectonic dislocations in the Quaternary strata in the northern part of Jylland are seen at Lønstrup (Jessen 1931) where marine Weich- selian deposits are dislocated in a thin-skinned thrust complex. Additionally, five well logs were found where marine Eemian deposits are repeated (Fig. 7). Most of the dislocations in the northern part of Jylland seem to involve only Quaternary deposits.

The majority of wells drilled through dislocated Interglacial marine deposits occur south of Fyn on the islands of Erø and Als, and in the nearby surroundings on Fyn and southeast Jylland.

\section{Intensity of glaciotectonic deformation}

The distribution of concealed glaciotectonic deformation recorded in wells is widespread but shows a higher concentration in certain areas. In order to get a general 
view of the regional distribution of the density of wells exhibiting glaciotectonic deformation, a grid is constructed. Each grid cell is $5 \times 5 \mathrm{~km}$, and for each cell the number of wells exhibiting deformation are computed. As the wells in the ZEUS database are not equally distributed (Fig. 2), a correction must be undertaken to account for this. The number of wells exhibiting glaciotectonic deformation is divided by the total number of wells in each grid cell (Fig. 8). This procedure gives a fairly good estimation of the density of wells exhibiting glaciotectonic deformation. In grid cells with only a few wells there might be an over or under representation of wells with concealed glaciotectonic deformation. On a large regional scale though, a cluster of cells showing a high density of wells with concealed glaciotectonic deformation are considered significant, and it is possible to identify regions with a higher density of wells with glacio-tectonic deformations - thus with high intensity of deformation.

\section{Comparison of well data and record of glaciotectonics}

Outside the Main Stationary Line there are several regions with high intensity of deformation where the wells exhibiting glaciotectonic deformation are situated within the 'hilly islands' as well as in areas covered by the Late Weichselian outwash plane. There are many exposures of Upper Miocene deposits recorded outside the Main Stationary Line, and most of them are glaciotectonically dislocated (Rasmussen 1966). Deformation of marine Holsteinian deposits are reported from the western part of Jylland near Esbjerg (Rasmussen 1966, Andersen 1967) and from a well $i$ the south western part of Jylland at Tornskov (Andersen 1963, Knudsen \& Penny 1987) (Fig. 7).

In the western part of the Limfjord, the intensity of glaciotectonic deformation is very high. This is in good agreement with the numerous coastal cliff exposures of glaciotectonic complexes and ice-push ridge systems described in this area (Gry 1940, 1979, Håkansson \& Sjørring 1982, Pedersen \& Petersen 1987, Pedersen 1993, Klint \& Pedersen 1995). The deformation complexes in this region usually involve pre-Quaternary bedrock, deformed during Weichselian ice advances.

East of the high intensity region in the Limfjord area, there is a region, with high intensity of glaciotectonic deformation extending in a northwest to southeast direction. It coincides with the overall morphological trend in this region, outlined by a northwest to southeast oriented large scale ridge (Milthers 1948). Southwest of this region a similar morphological trend is seen and in this region deformation of Saalian as well as Weichselian age are described (Larsen et al. 1977, Kronborg et al. 1990).

Along the east coast of Jylland, from Djursland to
Germany, there is a very high intensity of glaciotectonic deformation, with the highest intensities east of the East Jylland Ice Border Line. Coastal cliff exposures in this region display extensive glaciotectonic deformation, in which Tertiary deposits, and in the southern part also interglacial deposits are dislocated along with Quaternary drift (Jessen 1930, 1935, 1945, Nordmann 1958, Konradi 1976, Houmark-Nielsen 1986, 1987).

In the region south of Fyn, on the islands Erø and Als, the intensity of glaciotectonic deformations is very high. In this region most of the recorded deformation involves dislocated interglacial marine deposits. The exposures in this region show that the interglacial marine deposits were deformed during several deformation phases in Weichsel, and that the deformation is extensive (Konradi 1976, Berthelsen 1979, Hansen 1987, 1994).

On the island of Fyn, glaciotectonic deformation is more widespread, except in the northeast of Fyn, at the Munkebo Ice-push ridge (Smed 1962). In this region several wells situated within the ice-push ridge system, exhibit glaciotectonic dislocated Palaeocene Kerteminde Marl (Jakobsen 1993).

On Sjælland, several regions with high intensity of glaciotectonic deformation can be pointed out. At the Røsnes peninsula a number of concealed dislocations can be related to the ice-push ridge, constituting the peninsula, in which Palaeocene Røsnes clay is dislocated (Petersen 1973). Southeast of Røsnes there is a region showing high density of concealed dislocations, arcuate in shape, with the concave side pointing to the southeast. Within this region several occurrences of dislocated Palaeocene Kerteminde Marl have been recorded (Hansen 1930).

Further to the southeast, there is an elongated northwest to southeast oriented region, with high intensity of glaciotectonic deformation. This region is situated northeast of an iceborderline, which is limiting the high concentration of deformation towards the southwest (Jacobsen 1981). The iceborderline is delineated by an ice-push ridge system, partially developed as hill-hole pair, genetically associated to a readvance from the northeast of the ice advance which reached the Main Stationary Line.

Northeast of this region, west and south west of Copenhagen, there are two regions with high intensity of glaciotectonic deformation.

The Copenhagen area appears as a region with high intensity. A closer inspection of the well logs reveal, however, that the majority of the pre-Quaternary units are locally derived limestone rafts or parautochthonous glacitectonites (Pedersen 1988), usually with a thickness less than one meter. In outcrops temporarily exposed due to construction works only minor glacio-tectonic deformations are seen within the Quaternary deposits in this area. The uppermost part of the Danian limestone is glacially tectonised (Knudsen et al. 1995) whereby the limestone rafts are detached from the pre- 
Quaternary surface and incorporated in the glacial deposits.

On the island of Møn there is a very high intensity of glaciotectonic deformation. Coastal exposures on Møn show extensive glaciotectonic deformation (Puggaard 1851, Hintze 1937, Berthelsen et al. 1977, Aber 1979, Berthelsen 1979, Houmark-Nielsen 1994), with Møns Klint as the most impressive feature, constituting a large composite ridge system.

\section{Discussion}

A well drilled through a glaciotectonically deformed rock body is a point observation which is a valuable supplement to the glaciotectonics observed in exposures. Much of the deformation recognised in this way is situated below late glacial or post glacial deposits.

The vast number of wells in the ZEUS database facilitates an analysis of the distribution and intensity of glaciotectonic deformation throughout the land area of Denmark. The possibility of detection of deformation in wells is, however, limited, as a recognisable lithological unit is required within the deformation complex. Nevertheless a large number of dislocations were detected in well logs, widely distributed throughout the country.

On a large scale, regions showing a high intensity of glaciotectonic deformations have been identified, and they are in good agreement with reports of glacio-tectonics within the regions. Hence the map showing the intensity (Fig. 8) supports field observations and outlines areas with a high degree of glaciotectonic deformation, and high glaciotectonic variability.

In areas with no or only few exposures, the inference of the high intensity of glaciotectonic deformation, based on the analysis of the well data, is consequently considered valid. In these areas, the information from well logs represent important data in the attempt to highlight glaciotectonic deformation and areas with high glaciotectonic variability. It should be emphasised, however, that the absence of evidence of deformation in wells in certain areas, does not preclude the existence of glaciotectonic deformation.

\section{Conclusions}

Mapping of glaciotectonic deformations involving preQuaternary and interglacial deposits has been carried out with the application of the well database ZEUS. Records of glaciotectonic dislocations are found widespread throughout Denmark. They are recognised in glacial terrain within morphological well-defined glaciotectonic complexes and in areas with no obvious glaciotectonic related morphology, and they are recog- nised in areas where the glacial deposits are covered with younger sediments.

The pre-Quaternary surface is highly affected by the dislocation of glacier-ice movements. The dislocated pre-Quaternary bedrock has usually not been transported long distances from source, although rafts of preQuaternary bedrock have in some cases been transported up to $50 \mathrm{~km}$ or more. The Eemian marine deposits are glaciotectonically deformed in areas affected by Weichselian ice advances, primarily southwest of Fyn and in north Jylland, and dislocated Holsteinian marine deposits are seen in a well in south Jylland.

On a large scale, it is possible to identify regions with a high intensity of glaciotectonic deformation. These are in good agreement with previous reports of glaciotectonics and glaciotectonic landforms. Regions without glaciotectonic related landforms but with a high intensity of glaciotectonic deformation can also be identified. In the high intensity regions, the glacio-tectonic deformation has created a high degree of lithological and stratigraphical variability.

\section{Acknowledgements}

I greatly appreciate the inspiring discussions with my colleagues at DGU, in particular Stig A. S. Pedersen, who also gave valuable criticism on the manuscript. I sincerely thank Frantz von Platen for his invaluable help on the data management and Jon R. Ineson for improvements in the English language.

\section{Dansk sammendrag}

Glaciale forstyrrelser påfører glaciale aflejringer og overfladenære prækvartære aflejringer en stratigrafisk såvel som lithologisk variabilitet. Den glacialtek-toniske variabilitet har store implikationer indenfor områder som råstofgeologi, hydrogeologi og geoteknik, hvorfor det er af stor betydning, at vide hvor der er forstyrrelser, $o g$ at kende graden af forstyrrelserne.

Glacialtektoniske forstyrrelser kan erkendes i boringsbeskrivelser, når boringen har penetreret prækvartære aflejringer, der hviler på glacigene aflejringer, og når interglaciale aflejringer gentages $i$ boreprofilet.

Der er foretaget en kortlægning af boringer der indeholder information om glacialtektoniske forstyrrelser, ud fra oplysninger i boredatabasen ZEUS, der indeholder boringsoplysninger fra ca. 140.000 boringer. Der er registreret 1210 boringer med dislocerede prækvartære aflejringer, og 49 boringer med dislocerede interglaciale aflejringer. Boringer med oplysninger om glacialtektoniske forstyrrelser er truffet vidt udbredt i Danmark. I det glaciale landskab er de truffet indenfor morfologisk veldefinerede glacialtektoniske komplek- 
ser, og i områder der ikke udviser nogen karakteristisk glacialtektonisk morfologi. Derudover er de truffet $\mathrm{i}$ områder, hvor de glaciale aflejringer er dækket af senglaciale og postglaciale sedimenter.

Prækvartær overfladen er stærkt påvirket af de glacialtektoniske forstyrrelser. De dislocerede prækvartære bjergarter er som regel ikke transporteret langt. Der er dog eksempler på flager der er transporteret op til $50 \mathrm{~km}$. De interglaciale marine Eem aflejringer er deformeret i Weichsel, primært i området sydvest for Fyn og i Nordjylland.

I stor skala er det muligt, at udpege områder med høj densitet af boringer, der indeholder oplysninger om glacialtektoniske forstyrrelser, og dermed høj intensitet af deformation. Mange af de udpegede områder med høj deformations intensitet, er i god overensstemmelse med beskrivelser af glacialtektoniske forstyrrelser, og morfologiske landskabsanalyser. Derudover er der udpeget områder med høj intensitet af glacialtektonisk deformation, $\mathrm{i}$ områder der ikke har glacialtektonisk relateret morfologi, som ikke ville kunne udpeges uden boringsoplysninger.

\section{References}

Aber, J. 1979: Kinetostratigraphy at Hvideklint, Møn, Denmark and its regional significance. Bulletin of the Geological Society of Denmark 28, 81-93.

Aber, J. 1988: Spectrum of constructional glaciotectonic landforms. In: Goldthwait, R. P. \& Matsch, C. L. (Eds): Genetic classification of glacigenic deposits, 281-292. A. A. Balkema, Rotterdam.

Aber, J. S., Bluemle, J. P., Bringham-Grette, J., Dredge, L. A., Sauchyn, D. J. \& Ackerman, D.L. 1993: Glaciotectonic Data Base and Mapping of North America. In Aber, J. S. (Ed.): Glaciotectonics and Mapping Glacial Deposits. Canadian Plains Research Center, University of Regina, 177200.

Aber, J. S., Croot, D. G. \& Fenton, M. M. 1989: Glaciotectonic Landforms and Structures. Glaciology and Quaternary Geology Series, Kluwer Academic Publishers, Dordrecht, Netherlands, $200 \mathrm{pp}$.

Andersen, S. T. 1963: Pollen analysis of the Quaternary Marine Deposits at Tornskov in South Jutland. Danmarks Geologiske Undersøgelse, IV Række, 4, 8, 23 pp.

Andersen, S. T. 1967: Istider og mellemistider. In Nørrevang, A \& Meyer, T.J. (Eds): Danmarks Natur. 1. Politiken, Copenhagen, 199-250.

Berthelsen, A. 1978: The methodology of kineto-stratigraphy as applied to glacial geology. Bulletin of the Geological Society of Denmark 27, Special Issue, 25-38.

Berthelsen, A. 1979: Contrasting views on the Weichselian glaciation and deglaciation of Denmark. Boreas 8, 125132.

Berthelsen, A., Konradi, P. \& Petersen, K. S. 1977: Kvartære lagfølger og strukturer i Vestmøns klinter. Dansk Geologisk Forening, Årsskrift for 1976, 93-99.
Croot, D. G. \& Michalak, W. 1993: The European Glaciotectonic Database Project. In Aber, J.S. (Ed.): Glacio-tectonics and Mapping Glacial Deposits. Canadian Plains Research Center, University of Regina, 251-258.

Gravesen, P. \& Fredericia, J. 1984: ZEUS-geodatabasesystem. Borearkivet. Databeskrivelse, kodesystem og sideregistre. Danmarks Geologiske Undersøgelse C3, 259 pp.

Gry, H. 1940: De istektoniske forhold i molerområdet. Meddelelser fra Dansk Geologisk Forening 9, 586-627.

Gry, H. 1979: Beskrivelse til Geologisk Kort over Danmark. Kortbladet L $\emptyset g s t \varnothing r$. Kvartære aflejringer. Danmarks Geologiske Unders $\varnothing$ gelse, I. række, 26, 58 pp.

Hansen, M. 1987: En kvartærgeologisk beskrivelse af Erø. Unpublished thesis, University of Copenhagen, $86 \mathrm{pp}$.

Hansen, M. 1994: Geological map of Denmark. 1:50000. Map sheet 1311 IV Mommark and part of 1311 I Rudkøbing. Geological basic data map. Geological Survey of Denmark. Map Series, 41.

Hansen, S. 1930: Om forekomster af Glacialflager af Paleocæn Mergel paa Sjælland. Danmarks Geologiske Undersøgelse. IV. Række, 2, 7, 22 pp.

Hansen, S. \& Milthers, K. 1954: Geologisk kort over Danmark. Hovedtræk i det Danske landskab. Danmarks Geologiske Unders $\varnothing$ gelse.

Hintze, V. 1937: Møens Klints geologi. C. A. Reitzel, Copenhagen, $410 \mathrm{pp}$.

Houmark-Nielsen, M. 1994: Late Pleistocene stratigraphy, glaciation chronology and Middle Weichselian environmental history from Klintholm, Møn, Denmark. Bulletin of the Geological Society of Denmark 41, 181-202.

Houmark-Nielsen, M. 1987: Pleistocene stratigraphy and glacial history of the central part of Denmark. Bulletin of the Geological Society of Denmark 36, 189 pp.

Houmark-Nielsen, M. 1986: Kortlægning af flagestrukturer og andre istektoniske forstyrrelser i Danmarks kvartær. Unpublished report, with maps covering map sheets 1211 , 1212 and 1213 .

Håkansson, E. \& Sjørring, S. 1982: Et molerprofil i kystklinten ved Salgerh $\varnothing \mathbf{j}$, Mors. Dansk Geologisk Forening, Årsskrift for 1981, 131-134.

Håkansson, E. \& Pedersen, S. A. S. 1992: Geologisk kort over den danske undergrund. Varv.

Jacobsen, E. M. 1981: Beskrivelse til ingeniørgeologisk kort Næstved. 1:25000. Nielsen \& Risager Aps. Rapport, 46 pp.

Jakobsen, P. R. 1993: Geological map of Denmark, 1:50000. Map sheet 1313 II Kerteminde. Geological basic data map. Danmarks Geologiske Unders $\emptyset$ gelse. Map series, 42.

Jakobsen, P. R. \& Pedersen, S. A. S. 1993: Geologisk opbygning af Junget molerfelt. Danmarks Geologiske Undersøgelse, Kunderapport nr. 72, 1993. 40 pp.

Jensen, K. E. S. K. 1992: En geologisk undersøgelse af et glacialtektonisk disloceret randmorænestrøg ved Hanklit på Nordmors. Unpublished thesis. Geological Institut, University of Copenhagen, $172 \mathrm{pp}$.

Jessen, A. 1930: Klinten ved Halkhoved. Danmarks Geologiske Undersøgelse. IV. række, 2, $26 \mathrm{pp}$.

Jessen, A. 1931: Lønstrup Klint. Danmarks Geologiske Unders $\emptyset$ gelse, II. række, 49, 142 pp.

Jessen, A. 1935: Beskrivelse til geologisk kort over Dan-mark. Kortbladet Haderslev. Danmarks Geologiske Undersøgelse. I. række, $17,95 \mathrm{pp}$.

Jessen, A. 1936: Vendsyssels Geologi. Danmarks Geologiske Undersøgelse. V. række, 2, 195 pp. 
Jessen, A. 1945: Beskrivelse til geologisk kort over Danmark. Kortbladet Sønderborg. Danmarks Geologiske Undersøgelse. I. rakke, 20, 41 pp.

Jørgensen, J., Hermansen, B. \& Jensen, J. H. 1993: Brugervejledning til ZETA. Miljøministeriets geografiske informationssystem, version 4.0. Danmarks Geologiske Undersøgelse, Datadokumentation, nr. 17, 1993, 582 pp.

Klint, K. E. S. \& Pedersen, S. A. S. 1995: The Hanklit Glaciotectonic Thrust Fault Complex, Mors, Denmark. Danmarks Geologiske Undersøgelse A35.

Knudsen, C., Jakobsen, P. R., Andersen, C., Larsen, B. \& Foged, N., 1995. Stratigraphy and engineering geology of København Limestone. Proceedings of the Eleventh European Conference on Soil Mechanics and Foundation Engineering, Copenhagen, 28 May-1 June. Danish Geotechnical Society, Bulletin 11, 5, pp. 5.117-5.126.

Knudsen, K. L. 1994: The marine Quaternary in Denmark: a rewiew of new evidence from glacial-interglacial studies. Bulletin of the Geological Society of Denmark 41, 203218.

Knudsen, K. L. \& Penny, D. N. 1987: Foraminifera and Ostracoda in Late Elsterian-Holsteinian deposits at Tornskov and adjacent areas in Jutland, Denmark. Danmarks Geologiske Unders $\emptyset$ gelse B10, 67 pp.

Konradi, P. B. 1976: Foraminifera in Eemian deposits at Stensigmose, southern Jutland. Danmarks Geologiske Undersøgelse. II. series, $105,57 \mathrm{pp}$.

Kluiving, S.J. 1994: Glaciotectonics of the Itterbeck-Uelsen push moraines, Germany. Journal of Quaternary Science 9, 235-244.

Kronborg, C., Bender, H., Bjerre, R., Friborg, R., Jacobsen, H. O., Kristiansen, L., Rasmussen, P., Sørensen, P. R. \& Larsen, G. 1990: Glacial stratigraphy of East and Central Jutland. Boreas 19, 273-287.

Larsen, G., Jørgensen, F. H. \& Priisholm, S. 1977: The stratigraphy, structure and origin of glacial deposits in the Randers area, eastern Jutland. Danmarks Geologiske Undersøgelse, II. række, $111,36 \mathrm{pp}$.

Madsen, V. 1916: Ristinge Klint. Danmarks Geologiske Unders $\emptyset$ gelse. IV. Række, 1, 32 pp.

Meyer, K. D. 1983: Saalian end moraines in Lower Saxony. In Ehlers (ed.): Glacial deposits in North-West Europe. A. A. Balkema, Rotterdam, 335-342.

Milthers, V. 1900: Randmoræner. In: Rørdam, K. \& Milthers, V. 1900: Kortbladene Sejrø, Nykøbing, Kalundborg og Holbæk. Danmarks Geologiske Undersøgelse. I. Række, 8, 69-83.

Milthers, V. 1943: Nordvestsjællands Geologi. Danmarks Geologiske Undersøgelse. V. række, 6, 185 pp.

Milthers, V. 1948: Det danske Istidslandskabs Terrænformer og deres opståen. Danmarks Geologiske Unders $\emptyset$ gelse, III. Række, 28, 234 pp.

Nordmann, V. 1958: Beskrivelse til geologisk kort over Danmark. Kortbladet Fredericia. A: Kvartære aflejringer. Danmarks Geologiske Undersøgelse I. Række, 22-A, 125 pp.

Pedersen, S. A. S. 1988: Glaciotectonite: Brecciated sediments and cataclastic sedimentary rocks formed subglacially. In Goldthwait, R.P. \& Matsch, C.L. (Eds): Genetic Classification of Glacigenic Deposits. Balkema, Amsterdam, 89-92.

Pedersen, S. A. S. 1993: The Glaciodynamic Event and Glaciodynamic Sequence. In Aber, J.S. (Ed.): Glaciotectonics and Mapping Glacial Deposits. Canadian Plains Research Center, University of Regina, 67-85.
Pedersen, S. A. S. \& Petersen, K. S. 1987: Sand-filled frost wedges in glaciotectonically deformed mo-clay on the island of Fur, Denmark. In Croot, D.G. (Ed.): Glaciotectonics. Forms and Processes. Balkema, Rotterdam, 185190.

Petersen, K. S. 1973: Tills in dislocated drift deposits on the Røsnæs peninsula, Northwestern Sjælland, Denmark. Bulletin of the Geological Institute of the University of Uppsalla, 5, 41-49.

Puggaard, C. 1851: Møns geologi. Guldmedalje afhandling. Københavns Universitet, 279 pp.

Rasmussen, H.W. 1977: Geologi på Mols. Rapport udarbejdet for Fredningsplanudvalget for Århus Amt. Danmarks Geologiske Undersøgelse. A4, 22 pp.

Rasmussen, L.B. 1966: Molluscan Faunas and Biostratigraphy of the Marine Younger Miocene Formations in Denmark. Part I: Geology and Biostratigraphy. Danmarks Geologiske Undersøgelse II. Rakke, 88, 358 pp.

Ringberg, B., Holland, B. \& Miller, U. 1984: Till stratigraphy and provenance of the glacial chalk rafts at Kvarnby and Ängdala, southern Sweden. Striae 20, 79-90.

Smed, P. 1962: Studier over den fynske øguppes glaciale landskabsformer. Meddelelser fra Dansk Geologisk Forening 15. 1-74.

Smed, P. 1982: Landskabskort over Danmark. Mapsheets 14. Geografforlaget, Brenderup.

van der Wateren, F.M. 1985: A model of glacial tectonics, applied to ice-pushed ridges in the central Nederlands. Bulletin of the Geological Society of Denmark 34, 55-74. 